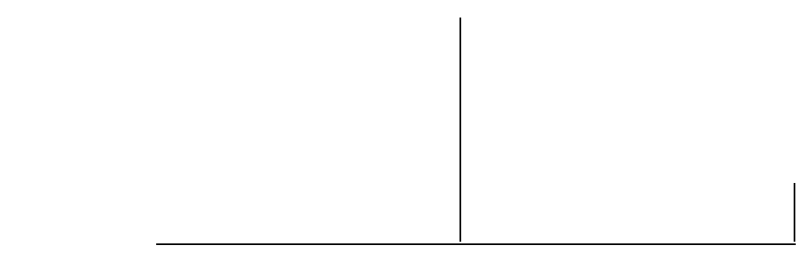

Rev. Latinoam. Psicopat. Fund., X, 3, 559-561

Adolescentes

Marta Rezende Cardoso (org.)

São Paulo: Escuta, 2006, 216 págs.

\title{
Por que se debruçar sobre a temática da adolescência?
}

Tempo crucial de impasse na subjetividade, entre o passado e o futuro, a adolescência implica não somente modificações físicas mas, sobretudo, um trabalho psíquico a operar. Momento da existência em que os laços com os primeiros objetos infantis precisam ser abandonados, uma experiência de ruptura necessária e constitutiva para abrir espaço ao investimento em novos objetos. É o tempo em que a subjetivação levará sua trama para além dos limites da família e das significações parentais. A adolescência coloca em questão as possibilidades construídas na infância para o encontro com outros objetos, as possibilidades de criação e, sobretudo, as possibilidades do sujeito em se desenhar um lugar como sujeito no mundo, de se inserir em seu contexto cultural. Não menos importante então, torna-se a reflexão do laço social dentro de sua temporalidade, articulando subjetividade e cultura para a compreensão da temática da adolescência.

Esta compreensão da questão da adolescência vem impondo grandes desafios para a clínica psicanalítica, onde se observa o surgimento de novos quadros patológicos 


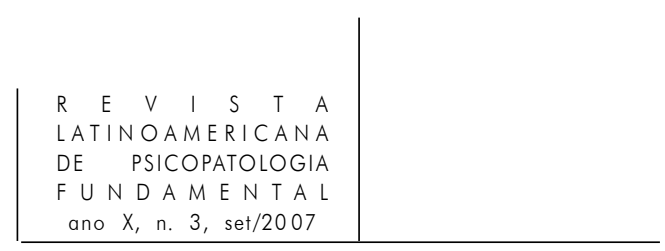

que, além do sofrimento individual, introduzem novos questionamentos, em um contexto mais amplo, sobre os efeitos dos operadores sociais atuais na construção do psiquismo e sobre as possibilidades de um laço social marcado pela crise da sociedade contemporânea, cada vez mais complexa.

O livro Adolescentes, organizado por Marta Rezende Cardoso, oferece uma leitura da adolescência que busca interpretar a questão em sua temporalidade, aportando importante contribuição para uma reflexão sobre o tema e, sobretudo, para quem aceita o desafio da clínica psicanalítica com adolescentes. A obra desperta o interesse e instiga a reflexão tanto do iniciante que vai em busca de experiências que possam orientar a compreensão da prática clínica, quanto do profissional já experiente, caso em que as contribuições oferecidas nos textos surpreendem o leitor pela sua originalidade e clareza. É, portanto, um livro que serve como referência aos profissionais que pretendem trabalhar com adolescentes ou que já se encontram nesta prática. Ele reúne 14 artigos de vários autores, que tratam aspectos extremamente pertinentes à questão da adolescência. Além da diversidade temática apresentada nessa coletânea de artigos, cabe salientar a participação conjunta, ao lado de autores já consagrados no cenário psicanalítico, de alunos de graduação em co-autoria com a organizadora, bem como alunos de pós-graduação que escreveram seus artigos em co-autoria com outros professores, orientadores de suas pesquisas ou supervisores de seus estágios na área clínica. Neste aspecto, o livro não só é um convite a se debruçar sobre o tema da adolescência, como um convite à escrita. A originalidade dos artigos reside nas reflexões que articulam subjetividade e cultura e na riqueza oferecida pela apresentação de casos clínicos, trazendo grande contribuição para a clínica psicanalítica com adolescentes. O livro é organizado em duas partes.

Em um primeiro tempo, a coletânea de artigos apresentados situa a adolescência na experiência coletiva contemporânea, apontando as dificuldades em atravessar esse processo conturbado por sua natureza psíquica, dificuldades que se somam na realidade exterior do cenário atual. Articulando subjetividade e cultura, os autores enfatizam a questão do laço social contemporâneo, o enfraquecimento dos limites e da autoridade e seus efeitos na mudança dos modos de relação com o objeto. Da mesma forma, apresentam reflexões sobre os aspectos da transição no contexto sociocultural atual, a qual remete ao declínio da autoridade simbólica, levando a uma exacerbação do desamparo. As contribuições trazidas nos textos, alguns dos quais trazem a explanação de fragmentos clínicos, são tratadas de forma aprofundada, oferecendo material teórico bastante pertinente ao tema. O segundo momento do livro reúne artigos elaborados em co-autoria. A organizadora da obra e seus alunos, estagiários em clínica e pesquisa da equipe na Divisão de Psicologia Aplicada do Instituto de 


\begin{tabular}{c|c} 
& \\
RESENHAS \\
DE LIVROS \\
ano $X, n .3$, set $/ 2007$ \\
\hline
\end{tabular}

Psicologia da UFRJ na qual é coordenadora, apresentam textos em que a reflexão teórica acompanha relatos de casos clínicos comentados.

A riqueza da diversidade temática desta coletânea e a preocupação em articular teoria e clínica na questão da adolescência dentro dos atuais quadros patológicos, em uma análise realizada através de diferentes perspectivas é, sem dúvida, de excelente contribuição para elucidar a delicada transição que impõe a passagem adolescente, nas múltiplas facetas que se apresentam no cenário de nossa cultura atual. 